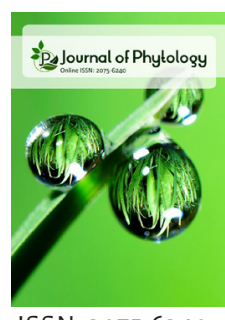

ISSN: $2075-6240$

\title{
Annihilating efficacy of Euphorbia birta L. extracts on Artemia salina Nauplii and human breast adenocarcinoma cells (MCF-7 \& MDA-MB-231)
}

\author{
Ramasamy Elankanni', Devanga Ragupathi Naveen Kumar² and \\ Rangasamy Ashok Kumar'*
}

'Department of Zoology, Government Arts College, Dharmapuri - 636 705, Tamil Nadu, India, ${ }^{2}$ Department of Clinical Microbiology, Christian Medical College, Vellore - 632 004, Tamil Nadu, India

Received: February 26, 2021

Revised: June 27, 2021

Accepted: July 04, 2021

Published: July 17, 2021

*Corresponding Author:

R. Ashok Kumar

E-mail: rangasamyashok@gmail. com

\begin{abstract}
Cancer is a leading cause of death both in developed and developing countries. Recently the secondary metabolites produced by plants are being investigated due to their promising anticancer activities. Accordingly, in the current study the anti-cancer potentials of Euphorbia hirta L., a renowned medicinal plant was explored for its anticancer activity. The methanol and aqueous extracts of Euphorbia hirta L. (EHA and EHM) were tested for their toxicity against Artemia salina nauplii, and for cytotoxic potentials in MDA-MB-23l and MCF-7 human breast adenocarcinoma cell lines. Both the extracts EHA and EHM showed maximum toxicity towards Artemia salina among which the methanol extract was able to annihilate all the nauplii in its highest concentration. Excitingly, Euphorbia hirta L. extracts exhibited potent cytotoxicity selectively against human breast cancer cells (MDA-MB-23l and MCF-7) than in normal cells (VERO). In conclusion, the results suggest that EHM extract of the selected plant might possess beneficial ingredients to treat human breast cancers especially against ER-positive breast cancer.
\end{abstract}

KEYWORDS: Euphorbia hirta L., Artemia salina, selective-cytotoxicity, human breast cancer, MCF-7, MDA-MB-231

\section{INTRODUCTION}

Cancer is well-known as a multifactorial disease due to abnormal proliferation of cells and is one of the major causes of death worldwide. Various genetic and epigenetic events create an accumulative phenomenon that lead to cancer development and progression (Wang et al., 2001). Treatment of cancer is particularly challenging and it inflicts a severe burden on the public health system. Conventional chemotherapy is associated with anticancer drugs with low therapeutic index and results in severe side effects (Khandare et al., 2006). Recent evidences suggest that natural products are good sources for the treatments of human diseases. Medicinal plants have been used to treat human diseases for centuries (Sharma and Moin, 2020). According to the World Health Organisation (WHO) few nations still rely on plant-based treatment as their main source of medicine (Parasuraman et al., 2014). The history dates back to several years in using plants for their medicinal benefits, especially for cancer (Conforti et al., 2008). Chemotherapy seems to be promising where $65 \%$ of the drugs used are of natural origin (Cragg \& Newman, 2005). Due to the above-said reasons, medicinal plants might prove potential to aid in the development of alternative therapy against cancer.

Euphorbia hirta L. is a very popular herb amongst practitioners of traditional herbal medicine and belongs to the Euphorbiaceae family. Traditionally, aqueous extracts of various E. hirta L. parts were noted to be used to treat various syndromes that include hay asthma, bowel disease, cough, bronchial disease, worm infestation, kidney stones, to decrease lactation, etc. They were also recorded for their benefits as a sedative, anxiolytic, analgesic, antipyretic, and anti-inflammatory agent. Furthermore, studies revealed that E. hirta L. possesses galactogenic, anti-anaphylactic, antimicrobial, antioxidant, anticancer, anti-feedant, antiplatelet aggregation, antiinflammatory, aflatoxin inhibition, antifertility, anthelmintic, anti-plasmodial, anti-amoebic, antimalarial and larvicidal activities (Rajeh et al., 2010). Based on the afore-mentioned

Copyright: $\odot$ The authors. This article is open access and licensed under the terms of the Creative Commons Attribution License (http://creativecommons.org/licenses/by/4.0/) which permits unrestricted, use, distribution and reproduction in any medium, or format for any purpose, even commercially provided the work is properly cited. Attribution - You must give appropriate credit, provide a link to the license, and indicate if changes were made. 
literature, the aqueous and methanol extracts of E. hirta L. were investigated to identify potential anticancer properties.

\section{MATERIALS AND METHODS}

\section{Plant Materials}

The fresh plants of E. hirta L. was collected from its natural habitat from Indur village of Dharmapuri district (Tamil Nadu, India). Collected specimens were recorded by maintaining a voucher specimen (GACDPIEH1) in the laboratory for future references. Whole plants were subjected to shade drying and powdered coarsely in a mechanical mixer-grinder.

\section{Preparation of Extracts}

Hot extraction was performed in a soxhlet apparatus for the powdered plant material using methanol and water as solvents [sample $(\mathrm{g})$ : methanolic/aqueous) $=1: 6$ ratio]. Obtained extracts were then concentrated in rotavapor R-215 (BUCHI Labortechnik AG, Switzerland) under reduced pressure (72 mbar) at $40^{\circ} \mathrm{C}$ to yield dry extracts. Concentrated extracts were then stored in a vacuum desiccator at room temperature until further use. The extracts were named as EHA (Euphorbia hirta L. aqueous) and EHM (Euphorbia hirta L. methanol).

\section{Brine Shrimp Lethality Assay (BSLA)}

Toxicity of the plant extracts were evaluated primarily on brine shrimp, Artemia salina nauplii. The lethality assay was performed following the method of Meyer et al. (1982). Briefly, eggs were obtained from STORI Salt Lake Artemia Cysts, Fish Cave Seller, Howrah, WB, India and stored at $4^{\circ} \mathrm{C}$ in a refrigerator until further use. $1 \mathrm{~g}$ of the cysts was sprinkled into the glass container ( $1 \mathrm{~L}$ capacity) containing sterile artificial sea water (prepared by dissolving $38 \mathrm{~g}$ of sea salt in 1 litre of sterile water) for hatching. This setup was incubated at room temperature $\left(25-29^{\circ} \mathrm{C}\right)$ for $24 \mathrm{hrs}$ with strong aeration and continuous light regime. Following which, newly hatched pinkcoloured free-swimming nauplii were harvested from the bottom of the container. Different dilutions of the plant extracts for this assay were prepared by adopting the procedure of McLaughlin et al. (1998). 20mg of the aqueous and methanol plant extracts were separately dissolved in $2 \mathrm{ml}$ of suitable solvents (stock solution). These were further diluted to prepare a series of concentrations 1000, 100, 10, and lppm $(\mu \mathrm{g} / \mathrm{ml})$.

The assay system was prepared with $4.5 \mathrm{ml}$ of sterile seawater containing $0.5 \mathrm{ml}$ of the chosen concentration of the plant extracts in watch glass and transferred with 10 nauplii. The setup was allowed to remain for $24 \mathrm{hrs}$, under constant illumination of florescent lamp and the number of survived and dead nauplii were counted and recorded with a hand lens. Larvae were considered dead if they did not exhibit any internal or external movement during several seconds of observation. Experiments were performed in triplicates including solvent and a negative control. Percentage mortality of the extracts was calculated using the formula: \% Mortality $=$ No. of dead nauplii/Total
No. of nauplii $\times 100 . \mathrm{LC}_{50}$ values were estimated using a probit regression analysis (Finney, 1971) at $95 \%$ confidence intervals.

\section{Cell Cultures and Maintenance}

MDA-MB-231 (human breast carcinoma), MCF-7 (human breast carcinoma) and VERO (African Monkey kidney epithelial) cell lines were procured from National Centre for Cell Science (Pune, India). MDA-MB-231 cells were maintained in L-15 (Leibovitz's) culture medium, and MCF-7 and VERO were maintained in Minimum essential medium (MEM) (Eagle) with Non-essential amino acids, all with $10 \%$ fetal bovine serum in a humidified atmosphere at $37^{\circ} \mathrm{C}$ (with $5 \% \mathrm{CO}_{2}$ for MCF-7 and VERO only). The cell lines were maintained in their growing phase at $70 \%$ confluency with regular passaging.

\section{Cytotoxicity Assay}

MTT assay was performed as described by Mosmann (1983) with slight modifications. Briefly, a 96-well plate was seeded with a cell concentration of 10,000 cells from column 2-11 and each well were made up to $200 \mu \mathrm{l}$ using respective fresh medium. $200 \mu \mathrm{l}$ of fresh culture medium alone was loaded in control columns 1 and 12. All sides of the plate was sealed and incubated at $37^{\circ} \mathrm{C}$ in a humidified atmosphere for $24 \mathrm{hrs}$. After 24hrs, existing medium was aspirated and wells were replenished with $200 \mu$ l of media containing varying concentrations (12.5, $25,50,100,200 \mu \mathrm{g} / \mathrm{ml}$ ) of plant extracts and incubated for 24hrs. After incubation, the extract medium was aspirated and fresh medium was added along with $10 \mu \mathrm{l}$ MTT reagent (final concentration of $0.45 \mu \mathrm{g} / \mathrm{ml}$ ). The plate was then covered with aluminium foil and placed for incubation in a humidified atmosphere for 4 hours at $37^{\circ} \mathrm{C}$. After which, the medium with MTT was removed and $100 \mu$ l Solubilization solution (DMSO) was added to each well to dissolve formazan crystals. Absorbance was recorded at $570 \mathrm{~nm}$ using a Dynex Opsys MR ${ }^{\mathrm{TM}}$ Microplate Reader (Dynex Technologies, VA, USA) with a $630 \mathrm{~nm}$ reference filter. Wells containing cells without extract treatments served as the control. Percentage cytotoxicity was calculated by using the formula:

$$
\% \text { Cytotoxicity }=\frac{A_{c}-A}{A_{c}} \times 100
$$

Where, $\mathrm{A}_{c}$ is the Absorbance of control cells and $\mathrm{A}$ is the absorbance of the extract treated cells

The $\mathrm{IC}_{50}$ value was determined by using linear regression equation i.e. $\mathrm{Y}=\mathrm{Mx}+\mathrm{C}$.

Here, $\mathrm{Y}=50, \mathrm{M}$ and $\mathrm{C}$ values were derived from the viability graph.

\section{Statistical Analysis}

All analyses were carried out in triplicates. For each assay, data were presented as mean \pm SD from three independent experiments $(n=3)$. Statistical analyses were performed by 
one-way ANOVA and significant differences between groups were determined at $\mathrm{P}<0.05$. To evaluate relationships between experimental parameters, results were analyzed for correlation and tested for significance by Student's t-test $(\mathrm{P}<0.05)$. MATLAB ver. 7.0 (Natick, MA, USA), GraphPad Prism 5.0 (San Diego, CA, USA) and Microsoft Excel 2007 (Roselle, IL, USA) were used for the statistical and graphical evaluations.

\section{RESULTS AND DISCUSSION}

Cancer is the most common and deadly diseases in the modern era and in addition, adverse effects of synthetic anticancer drugs are the major limitations in treating cancer. In Asian cultures, medicinal plants are used traditionally to prevent and treat cancers. Medicinal plants have been reported as a good source for the discovery of new chemotherapeutic drugs with high efficiency and fewer side effects (Harvey \& Cree, 2010).

\section{Yield of extracts}

Extraction is an important step for the detection of bioactive components from plant materials. With the aid of a solvent, desirable constituents are removed from those that are not required from the plant material (Dhanani et al., 2017). In the present study, fifty grams of E. hirta L. whole plant powder upon soxhlet extraction resulted in a yield of $9.2 \mathrm{~g}$ (percentage extract yield: $18.4 \%$ of dry weight) of aqueous (EHA) and $7.3 \mathrm{~g}$ (percentage extract yield: 14.6\% of dry weight) of methanol (EHM) crude extracts. The sample was further stored in a vacuum desiccator until further use.

\section{Brine shrimp lethality bioassay}

The brine shrimp lethality bioassay is widely used in the evaluation of toxicity of heavy metals, pesticides, plant extracts, etc. It's a preliminary toxicity screen for further experiments on mammalian animal models (Price et al., 1974; Sorgeloos et al., 1978). The brine shrimp assay has advantages of being rapid (24hrs), inexpensive, and simple. It easily utilizes a large number of organisms for statistical validation and requires no special equipment (McLaughlin et al., 1998). Both methanol and aqueous extracts of E. hirta L. exhibited significant mortality against Artemia nauplii. The percentage mortality for E. hirta L. whole plant aqueous and methanol extracts were depicted in (Table 1 and Table 2). Accordingly, EHA exhibited percentage mortality ranging from $27 \%$ to $73 \%$ whereas, EHM exhibited $50 \%$ to $100 \%$ mortality at $1 \mu \mathrm{g} / \mathrm{ml}$ to $1000 \mu \mathrm{g} / \mathrm{ml}$ concentrations. EHM found to exhibit better mortality in A. nauplii when compared to EHA with an $\mathrm{LC}_{50}$ of $1 \pm 5.4 \mu \mathrm{g} / \mathrm{ml}$ than the later $43.25 \pm 9.6 \mu \mathrm{g} / \mathrm{ml}$. As mentioned by Meyer (1982), both the plant extracts exhibited an $\mathrm{LC}_{50}$ value of less than $1000 \mu \mathrm{g} / \mathrm{ml}$ which is considered toxic. The methanol extract (EHM) in its highest concentration $(1000 \mu \mathrm{g} / \mathrm{ml})$ had killed all the napulii treated.

\section{Selective-cytotoxicity of EHA and EHM towards breast cancer cells}

The efficacy of E. hirta L. extracts to inhibit the proliferation of cancer cells were further evaluated using two cancer cells (MDA-MB-231 and MCF-7) and a normal cell (VERO). Both the extracts have exhibited significant cytotoxicity in cancer cells when compared to normal cell (Figure 1 and Figure 2). Similar results were also made by Weisburg et al. (2004), wherein selective destruction of cancer cells was demonstrated. Among the study extracts, EHM had lower $\mathrm{IC}_{50}$ values of 82.81 and $24.31 \mu \mathrm{g} / \mathrm{ml}$ than EHA (92.86 and $53.08 \mu \mathrm{g} / \mathrm{ml}$ ) in MDA-MB-231 and MCF-7 cells respectively. The extracts EHA and EHM were more effective in controlling the proliferation of MCF-7 cells rather than MDA-MB-231 cells. According to the American National Cancer Institute (NCI), the crude plant extract with an $\mathrm{IC}_{50}$ value $<30 \mu \mathrm{g} / \mathrm{ml}$ indicates the promising plant material for further cytotoxic agent purification (Suffness and Pezzuto, 1990). Accordingly, the extracts, EHA and EHM had lower $\mathrm{IC}_{50}$ values in MCF-7 cells, close and within the range of reported values by NCI when compared to the values of these extracts in MDAMB-231 cells. Moreover, VERO cells had recorded the maximum

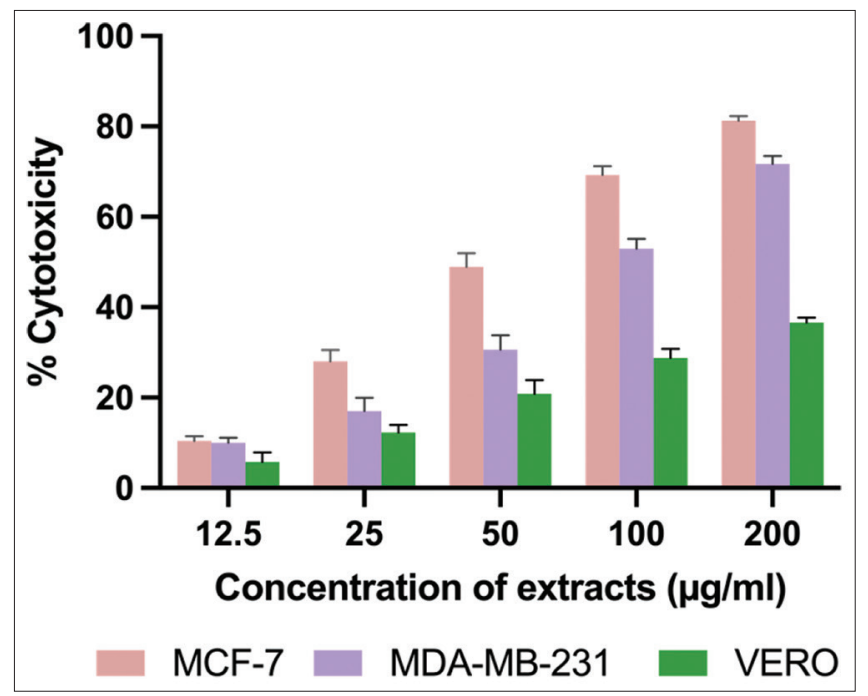

Figure 1: Cytotoxicity of EHA on MDA-MB-231 and MCF-7 breast adenocarcinoma cells, and VERO cell lines

Table 1: Percentage mortality and LC50 value of $A$. sallina nauplii after 24 hrs post exposure to the $E$. hirta $L$. whole plant aqueous extract (EHA).

\begin{tabular}{|c|c|c|c|c|c|c|c|c|c|c|}
\hline \multirow[t]{2}{*}{ SI. No. } & \multirow{2}{*}{$\begin{array}{l}\text { Conc. of Plant extract } \\
\text { (ppm or } \mu \mathrm{g} / \mathrm{mL})\end{array}$} & \multirow{2}{*}{$\begin{array}{l}\log C \\
\text { Conc. }\end{array}$} & \multicolumn{4}{|c|}{ Number of Surviving Nauplii after $24 \mathrm{hrs}$} & \multirow[t]{2}{*}{ Mean \pm SD } & \multirow[t]{2}{*}{$\%$ Mortality } & \multirow{2}{*}{$\begin{array}{l}\text { Probit \% } \\
\text { Mortality }\end{array}$} & \multirow{2}{*}{$\begin{array}{c}\mathrm{LC}_{50} \\
(\mu \mathrm{g} / \mathrm{ml})\end{array}$} \\
\hline & & & T1 & $\mathrm{T} 2$ & T3 & Total & & & & \\
\hline 1 & 1 & 0 & 8 & 7 & 7 & 22 & $7.33 \pm 5.77$ & 27 & 4.39 & \\
\hline 2 & 10 & 1 & 6 & 5 & 3 & 14 & $4.67 \pm 15.20$ & 53 & 5.08 & $43.25 \pm 9.56$ \\
\hline 3 & 100 & 2 & 4 & 3 & 4 & 11 & $3.67 \pm 5.77$ & 63 & 5.33 & \\
\hline 4 & 1000 & 3 & 4 & 2 & 2 & 8 & $2.67 \pm 11.50$ & 73 & 5.61 & \\
\hline
\end{tabular}

Note: ${ }^{*} \mathrm{~T}=$ Trial (No. of nauplii taken in each trial $=10$ ); There is no probit value for $0 \%$ and $100 \%$ 
Table 2: Percentage mortality and LC50 value of $A$. sallina nauplii after $24 \mathrm{hrs}$ post exposure to the $E$. hirta L. whole plant methanol extract (EHM).

\begin{tabular}{|c|c|c|c|c|c|c|c|c|c|c|}
\hline \multirow{2}{*}{$\begin{array}{l}\text { SI. } \\
\text { No. }\end{array}$} & \multirow{2}{*}{$\begin{array}{l}\text { Conc. of Plant extract } \\
\text { (ppm or } \mu \mathrm{g} / \mathrm{mL})\end{array}$} & \multirow{2}{*}{$\begin{array}{l}\log C \\
\text { Conc. }\end{array}$} & \multicolumn{4}{|c|}{ Number of Surviving Nauplii after 24 hrs } & \multirow[t]{2}{*}{ Mean \pm SD } & \multirow[t]{2}{*}{$\%$ Mortality } & \multirow{2}{*}{$\begin{array}{l}\text { Probit \% } \\
\text { Mortality }\end{array}$} & \multirow{2}{*}{$\begin{array}{c}\text { LC50 } \\
(\mu \mathrm{g} / \mathrm{ml})\end{array}$} \\
\hline & & & $\mathrm{Tl}$ & T2 & T3 & Total & & & & \\
\hline 1 & 1 & 0 & 6 & 4 & 5 & 15 & $5.00 \pm 10.00$ & 50 & 5.00 & $1 \pm 5.39$ \\
\hline 2 & 10 & 1 & 4 & 3 & 3 & 10 & $3.33 \pm 5.77$ & 67 & 5.44 & \\
\hline 3 & 100 & 2 & 2 & 2 & 3 & 7 & $2.33 \pm 5.77$ & 77 & 5.74 & \\
\hline 4 & 1000 & 3 & 0 & 0 & 0 & 0 & $0.00 \pm 0.00$ & 100 & 0 & \\
\hline
\end{tabular}

Note: ${ }^{*} \mathrm{~T}=$ Trial (No. of nauplii taken in each trial $=10$ ); There is no probit value for $0 \%$ and 100

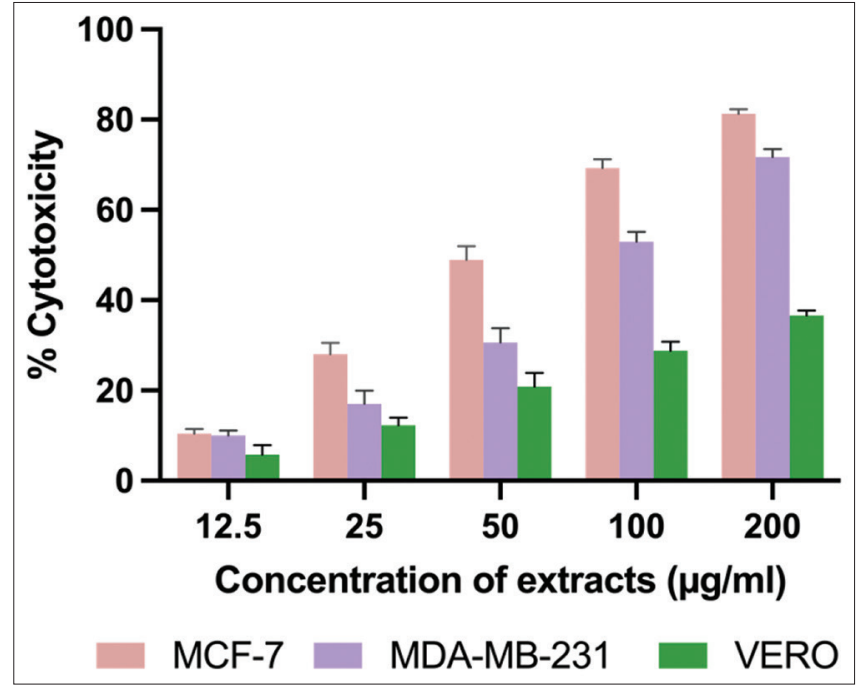

Figure 2: Cytotoxicity of EHM on MDA-MB-231 and MCF-7 breast adenocarcinoma cells, and VERO cell lines

$\mathrm{IC}_{50}$ values, 689.32 and $226.69 \mu \mathrm{g} / \mathrm{ml}$ for the extracts EHA and EHM, respectively which indicates significantly $(\mathrm{P}<0.05)$ lower cytotoxicity in these cells. Hence, the results reveal that the E. hirta L. extracts were selectively targeting cancer cells and more specifically ER-positive breast cancer cells (MCF-7).

\section{CONCLUSION}

The study has revealed that the aqueous and methanol extracts of E. hirta L. plant had higher toxicity against the Brine shrimp, A. salina nauplii, where the methanol extract could annihilate all of the napulii in its highest concentration. Both the extracts exhibited higher cytotoxicity in cancer cells (MCF-7 and MDAMB-231) when compared to normal VERO cells. The results clearly indicate that both the extracts might possess beneficial therapeutic components specifically against ER-positive breast cancer with lesser damage towards normal cells. Hence, these extracts may further be exploited to isolate novel and potential sources of anticancer agents.

\section{REFERENCES}

Conforti, F., Sosa, S., Marrelli, M., Menichini, F., Statti, G. A., Uzunov, D., Tubaro, A., Menichini, F., \& Loggia, R. D. (2008). In vivo antiinflammatory and in vitro antioxidant activities of mediterranean dietary plants. Journal of Ethnopharmacology, 116(1), 144-151. https://doi.org/10.1016/j.jep.2007.11.015

Cragg, G. M., \& Newman, D. J. (2005). Plants as a source of anti-cancer agents. Journal of Ethnopharmacology, 100(1-2), 72-79. https://doi. org/10.1016/j.jep.2005.05.011

Dhanani, T., Sonal, S., Gajbhiye, N. A., \& Kumar, S. (2017). Effect of extraction methods on yield, phytochemical constituents and antioxidant activity of Withania somnifera. Arabian Journal of Chemistry, 10(1), S1193-S1199. https://doi.org/10.1016/. arabjc.2013.02.015

Finney, D. (1971). Probit analysis, third ed. Cambridge University Press, Cambridge.

Harvey, A. L., \& Cree, I. A. (2010). High-throughput screening of natural products for cancer therapy. Planta Medica, 76(11), 1080-1086. https://doi.org/10.1055/s-0030-1250162

Khandare, J., \& Minko, T. (2006). Polymer-drug conjugates: progress in polymeric prodrugs. Progress in Polymer Science, 31(4), 359-397. https://doi.org/10.1016/j.progpolymsci.2005.09.004

Mclaughlin, J. L., \& Rogers, L. L. (1998). The use of biological assays to evaluate botanicals. Drug Information Journal, 32(2), 513-524. https:// doi.org/10.1177/009286159803200223

Meyer, B. N., Ferrighi, N. R., Putnam, J. E., Jacobsen, L. B., Nichols, D. E., \& McLaughlin, J. L. (1982). Brine shrimp: A convenient general bioassay for active plant constituents. Planta Medica, 45(5), 31-34. https://doi. org/10.1055/s-2007-971236

Mosmann, T. (1983). Rapid colorimetric assay for cellular growth and survival: Application to proliferation and cytotoxicity assays. Journal of Immunological Methods, 65(1-2), 55-63. https://doi. org/10.1016/0022-1759(83)90303-4

Parasuraman, S., Thing, G. S., \& Dhanaraj, S. A. (2014). Polyherbal formulation: Concept of ayurveda. Pharmacognosy Reviews, 8(16), 73-80. https://doi.org/10.4103/0973-7847.134229

Price, K. S., Waggy, G. T., \& Conway, R. A. (1974). Brine shrimp bioassay and seawater BOD of petrochemicals. Journal - Water Pollution Control Federation. 46(1), 63-77.

Rajeh, B. M., Zuraini, Z., Sasidharan, S., Latha, L. Y., \& Amutha, S. (2010). Assessment of Euphorbia hirta L. leaf, flower, stem and root extracts for their antibacterial and antifungal activity and brine shrimp lethality. Molecules, 15(9), 6008-18. https://doi.org/10.3390/ molecules15096008

Sharma, G., \& Moin, S. (2020). Medicinal plants: a mini review. Journal of Environment, Science and Technology, 6 (1), 14-18.

Sorgeloos, P., Wielen, R. D. C., \& Persoone, G. (1978). The use of Artemia nauplii for toxicity tests - A critical analysis. Ecotoxicology and Environmental Safety, 2(3-4), 249-255. https://doi.org/10.1016/S01476513(78)80003-7

Suffness, M., \& Pezzuto, J. M. (1991). Assays related to cancer drug discovery. In: K. Hostettmann (Ed.), Methods in Plant Biochemistry: Assays for Bioactivity. (Vol. 6, pp. 71-133) London, Academic Press.

Wang, H., lakova, P., Wilde, M., Welm, A., Goode, T., Roesler, W. J., \& Timchenko, N. A. (2001). C/EBPalpha arrests cell proliferation through direct inhibition of Cdk2 and Cdk4, Molecular Cell, 8(4), 817-828. https://doi.org/10.1016/S1097-2765(01)00366-5

Weisburg, J. H., Weissman, D. B., Sedaghat, T., \& Babich, H. (2004). In-vitro cytotoxicity of epigallocatechin gallate and tea extracts to cancerous and normal cells from the human oral cavity. Basic and Clinical Pharmacology and Toxicology, 95(4), 191-200. https://doi. org/10.1111/j.1742-7843.2004.pto_950407.x 